УДК 177.3

DOI 10.35423/2078-8142.2021.1.1.05

Д. В. Усов,

доктор філософських наук, професор, Черкаський інститут пожежної безпеки імені Героїв Чорнобиля Національного університету циивільного захисту України, м. Черкаси, Украӥна e-mail:dimausov@i.ua ORCID: https://orcid.org/0000-0002-8898-9743

\title{
ФІЛОСОФІЯ СПРАВЕДЛИВОСТІ В РЕАЛІСТИЧНІЙ УТОПІЇ ДЖОНА РОЛЗА
}

У статті послідовно обтрунтовується думка про особливу методологічну та практичну актуальність філософії справедливості Джона Ролза до 50-ї річнииі публікачії його «Теорії справедливості» та 100-ліття з дня народження иього видатного філософа сучасності. Не лише «Теорія справедливості», а й такі важливі праиі Дж. Ролза, як «Історія моральної філософії» та «Справедливість як чесність» спрямовані на пошуки шляхів побудови чесної, гідної людини суспільства і постають перед нами в якості найвпливовіших текстів минулого століття з політичної філософіï, філософії права та моралі. Мислити про «справедливість як чесність» разом із Ролзом є плідною філософською стратегією. Саме таке уявлення обстоюють не лише послідовники, а й критики теорії справедливості Ролза. Як наголошується у статті, розпочинаючи свої роздуми над питанням справедливості, Дж. Ролз зазначає, щео справедливість як фундаментальна умова людського буття не припускає, щуоб втрата свободи одними виправдовувалася великими благами інших. Це втілилося у прагненні його "реалістичної утопії справедливості» розробити механізми справедливого подолання суспільних конфліктів. А безумовна важливість запропонованої нами послідовної реконструкиії взаємин справедливості та свободи в роздумах Дж. Ролза зумовлена ще й тим, щзо вони спричинили глибинний розвиток сучасної соціальної та політичної філософіï, розиирили ї̈ методологічний та понятійний обрії. Проте філософія справедливості Ролза (на чому наголошують та-

(c) Усов Д. В., 2021 
кі видатні філософи, як А. Гонет, М. Нуссбаум, Е. Тугендгат, Р. Форст) не вийшла за межі розподільного тлумачення справедливості $i$ залишила поза увагою головне питання справедливості (та несправедливості) - питання влади.

Ключові слова: Джон Ролз, справедливість, свобода, приничипи справедливості, справедливість як чесність, політична філософія.

Усе ще актуальне на сьогодні осмислення засадничих принципів та долі неметафізичної версії суспільної угоди та справедливості як чесності Джона Ролза зумовлене не лише століттям 3 дня його народження, а насамперед тим, що чеснота справедливості $\epsilon$ засадничою умовою людського буття. Засновуючи свої роздуми над питанням справедливості Дж. Ролз наголошує, що «справедливість не допускає, щоб втрата свободи одними виправдовувалася великими благами інших», а тому «виключається такий підхід, при якому баланс втрат і надбань різних людей розглядається так, як якщо б вони були однією особистістю», а «отже, в справедливому суспільстві основні свободи вважаються за загальноприйняті, і права, гарантовані справедливістю, не є предметом політичного торгу або ж калькуляції соціальних інтересів» [5, с. 56]. Саме на цьому вимірі проблеми справедливості якнайповніше закцентовані дослідження провідних політичних філософів сучасності. Зокрема, Ф. Немо у передмові до «Етики і Безкінечності» Е. Левінаса наголошує, що «найперше питання, через яке буття розкривається і усталюється людське як «інакше, ніж буття» і як трансценденція у світ, і без якого, навпаки, жодне інше запитання є марнотою і звіюється вітром - це питання справедливості» [3, с. 11]. Важливою для осмислення політичної філософії Дж. Ролза постає й праця Поля Рікера «Справедливе», в якій мислитель не просто виокремлює проблему справедливості як протидію насильству, приниженню людської гідності, де «обурення при зіткненні з несправедливим є значно більшим порівняно 3 тим, що Дж. Ролз називав «добре зваженими переконаннями» [4, с. 9]. Проте головне, що мусив здолати Ролз, віднайти відповідь на критичні закиди опонентів і справа, і зліва. «Ті, що справа, звинувачують його в егалітаризмі. Зліва ж його звинувачують у легітимації нерів- 
ності. Першій групі Ролз відповідає: в ситуації довільної нерівності перевагам тих, хто має найсприятливіші позиції, може загрожувати спротив бідних, або просто брак кооперації з їхнього боку. Другій групі він заявляє: більш егалітарне рішення було б одноголосно відкинуте, оскільки через нього всі терпіли б втрати» [4, с. 83].

На пошуки шляхів побудови чесного, гідного людини суспільства спрямовані не лише «Теорія справедливості», а й такі системні праці Дж. Ролза, як «Історія моральної філософії» та «Справедливість як чесність». Ці твори постають перед нами в якості найвпливовіших текстів-дороговказів минулого століття 3 політичної філософії, філософії права та моралі, що спонукає мислити про справедливість разом з Ролзом і $\epsilon$ плідною філософською стратегією. Саме у цьому річищі рухається О. Гьофе у своїй останній праці, присвяченій столітньому ювілею одного 3 найвпливовіших філософів і не лише минулого століття [3].

У межах реконструкції ролзівського дискурсу справедливості, втіленого в дилемі рівності та нерівності, свободи та рівноправності, доцільно звернулися до засад політичної філософії Дж. Ролза, насамперед до його версії контрактуалізму. Парадигмальні (що мають кілька вимірів) зрушення своєї теорії справедливості сам Ролз розпочинає 3 декларування прагнення розробити концепцію справедливості, що постане в якості розважливої та систематичної альтернативи утилітаризму, який тривалий час панував насамперед в англосаксонській філософії. Однією з причин суперечки з утилітаризмом постала викладена вже у передмові до «Теорії справедливості» зневіра Ролза у спроможності останнього «забезпечити задовільне витлумачення основних прав і свобод громадян як вільних і рівноправних осіб, що є вимогою щонайпершої важливості для обгрунтування демократичних інститутів», тому «я використовував більш загальне і абстрактне уявлення ідеї суспільного договору за допомогою ідеї вихідного положення», в якій «переконливе пояснення основних прав і свобод та їх пріоритету було головною метою справедливості як чесності» та, ставлячи за мету «об'єднання цього пояснення з розумінням демократичної рівності, що веде до принципу чесної рівності можливостей і принципу відмінності» [5, с. 12]. Таким чином, утилітаристський принцип «більшого щастя для більшості» у Ролза заступає контрактуалістичний за своєю сутністю принцип «справед- 
ливості як чесності», критичне осягнення якого, його еволюції та меж і є предметом даної статті.

Звертаючись до теорії справедливості Дж. Ролза як важливої засади сучасної політичної філософії насамперед зауважимо, що у вітчизняній філософії вже досить чітко виокремлюється низка проблем, які мусять набути подальшого розвитку і засновані вони на тезі про те, що «основною підвалиною суспільної угоди має бути принцип справедливості: коли люди розумні та максимально чесні, вони готові визнати та дотримуватися концепції справедливого суспільного устрою» [5, с. 101].

У самій ідеї суспільної угоди та іiї інтерпретації в теорії справедливості Дж. Ролза (частково дослідженої у працях Р. Зимовця, А. Срмоленка, Д. Кирюхіна, Н. Кудрявцевої, Л. Ситніченко, Д. Шевчука) втілені особливості парадигмального повороту цього харизматичного концепту справедливості. Адже, як далекосяжно наголошує Ю. Габермас, суспільний договір «виникає з ідеї про те, що кожен претендент на вступ до нього мусить мати раціональний мотив, аби добровільно стати його членом і підпорядкуватися відповідним нормам і процедурам. Когнітивний зміст, завдяки якому порядок стає моральним чи справедливим, спирається, отже, на спільну згоду всіх окремих його членів» [1, с. 26].

Зразком філософського дискурсу для Ролза, що цілком логічно, замість Дж. Бентама, постав I. Кант, який, як відомо, вважав, що загибель справедливості означає втрату тієї основної цінності, яка тримала б людей на світі. Саме у зверненні до моральної філософії Канта і полягає важлива особливість контрактуалізму Дж. Ролза. Постулюючи роздуми І. Канта в якості основного алгоритму модерного контрактуалізму, Ролз надає перевагу його поняттю автономії (параграф 40 «Теорії справедливості»).

Не випадково Дж. Ролз подає власну теорію справедливості як сучасну версію теорії суспільної угоди, коли остання розвивається та узагальнюється, не зважаючи на якусь конкретну форму суспільства чи врядування. Саме про це, як про основну мету роздумів класика сучасної політичної та соціальної філософії, йдеться вже у вступі до «Теорії справедливості». Як наголошує Ролз, він намагався «узагальнити на піднести на вищий рівень абстракції традиційну 
теорію суспільного договору, яку представляють Локк, Руссо і Кант» [5, с.19]. Філософ відзначає: «Сподіваюся, що саме в цей спосіб цю теорію можна так розвинути, аби вона перестала бути беззахисною перед найочевиднішими закидами, що часто здавалися фатальними для неї. До того ж ця теорія пропонує, як видається, альтернативний системний огляд справедливості» [5, с. 19].

Варто також зазначити, що саме завдяки «Теорії справедливості» (про що сам Ролз постійно говорить у вступі до праці та першій iii частині), через обгрунтування контрактуалістичного характеру філософії справедливості, договірна теорія знову набуває плідного методологічного та практичного сенсу. В іiї межах не просто узгоджуються плюралістично налаштовані інтереси та цінності, послаблюються істотні суперечності. Йдеться про певну домовленість вільних, розважливих, спроможних на непокору, громадян, які мають належні політичні права та обов'язки, володіють можливостями справедливого отримання рівних основних (або хоча б мінімальних) гідних можливостей для життя та розвитку, участі в суспільному житті. «Дея полягає не просто в сприянні тим, хто опиняється в програші через нещасливий випадок чи лихо, а в наданні усім громадянам змоги налагоджувати свої власні справи й брати участь у соціальній співпраці на основі взаємоповаги за відповідно рівних умов» $[5$, с. 16$]$.

Наголошуючи на тому, що усвідомити його «Теорію справедливості» досить складно, Ролз дивує і приваблює чіткістю та послідовністю викладу основних понять та принципів ідеї контрактуалізму. Розпочинаючи з розділу про «справедливість як чесність», Ролз акцентує увагу не лише на неможливості втрати свободи заради тих чи інших благ, але й на тій обставині, що «несправедливість буває стерпною лише тоді, коли необхідно уникнути ще більшої несправедливості» [5, с. 27].

Уже на початку першого розділу розкривається значущість ідеї суспільної угоди для залагодження соціальних конфліктів, коли кожен (якщо подивитися на людей критично) прагне для себе більшої частки з громадського пирога суспільних благ. Через це й виникає завдання - віднайти певні принципи, які б уможливили «вибрати найкраще 3 поміж численних можливих соціальних домовленостей, які визначають цей розподіл переваг, і щоб підписати угоду про на- 
лежні дистрибутивні частки» [5, с. 28]. Особливість означених принципів полягає в тому, що вони постають засадами соціальної справедливості, визначаючи розподіл не лише благ, а й обов'язків, за висловом Ролза: «тягарів соціальної співпраці».

Для того, щоб віднайти бажані принципи, варто, на думку Ролза, зробити кілька припущень, які й висвітлять сутність його контрактуалізму. По-перше, припустити, що «кожен діє справедливо й робить все від нього залежне для підтримання справедливих інституцій» [5, с. 33], а потім перейти до розгляду строгої та вибіркової згоди. А, по-друге, уявити, що люди саме гуртом обирають справедливі принципи: так само, як кожна розважлива людина визначає наміри свого життя та діяльності, так і будь-яка раціональна спільнота мусить у гіпотетичній ситуації рівної свободи визначати для себе те, що є справедливим, а що - ні. Звідси випливає значення та сенс «первісної позиції рівності», яка, як стверджує Ролз, відповідає природному станові у традиційній теорії суспільної угоди. Такий підхід має свою важливу особливість - він найповніше розкриває сутність визначення «справедливості як чесності».

Таким чином, звернення Ролза до концепту суспільної угоди $€$ невипадковим, оскільки критерієм справедливості є ті публічні засади, на яких громадяни можуть обгрунтувати їх спільні інституції. Розумні індивіди, на думку Ролза, прагнуть віднайти розважливий баланс між загальним благом та власним інтересом, бо їх метою $\epsilon$ суспільство, в якому вони могли б співпрацювати з іншими на добровільно взаємовизнаних засадах свободи і рівності. Взаємність «працює» тоді, коли кожен отримує переваги від співпраці, а розум та соціальна взаємодія виявляються прямо пов'язаними між собою. Для Ролза нерозумність (на що ніяк не хочуть звертати увагу критики ролзівського тлумачення особистості) полягає у порушенні принципу взаємності. Нерозумними є насамперед люди, які начебто хочуть спілкуватися та взаємодіяти з іншими людьми, проте не дуже то збираються дотримуватися загальних принципів та домовленостей щодо чесних умов взаємної співпраці. Та чи не реалістичним (на відміну від захопленого тлумачення комунітаристами індивідів як винятково альтруїстичних учасників спільноти) є погляд Ролза на 
людей як суб'єктів, спроможних порушити нетривкі умови співпраці, тільки-но це буде їм вигідно.

Ролз постійно, за допомогою «сократичного методу» рефлективної рівноваги, маневрує між теоретично обгрунтованими принципами та повсякденними моральними судженнями і в такий спосіб прагне хоч трохи подолати прірву, розрив між теоретичними конструктами справедливості та реальним життям. Таке обгрунтування справедливості не може спиратись на самоочевидності, а передбачає певну конструктивну процедуру, яка мусить узгодити «буденні» та «розумні» (моральні) судження. Ролз і називає такий метод «сократичним»: обгрунтованими принципами справедливості є ті принципи, що є прийнятними для вільних та рівних індивідів у вихідній ситуації, лише тоді, коли умови їх обгрунтування (свобода, рівність та взаємність) є проясненими та викладеними у рівновазі між принципами та «нашими» повсякденними моральними судженнями. Акцентуючи на тому, що в гіпотетичній «первісній» позиції відбувається раціоналізація принципів справедливості, створення таких принципів, які б співпадали із нашими повсякденними судженнями, Ролз ставить важливе запитання: «Чому, коли до тієї угоди, до тієї спілки ніхто й ніколи не входить, ми повинні хоч скількись цікавитися іiі принципами, моральними, чи ще якими? Відповідь буде та, що умови, втілені в описові первісної позиції, $є$ такими, які ми приймаємо в дійсності. А коли не приймаємо, то нас, либонь, можна умовити чинити так - умовити через філософську рефлексію. Кожен аспект ситуації суспільного договору можна підтвердити відповідними підставами. Тож ми зробимо так, що зберемо докупи, в одну концепцію, багато умов, якими обставлено принципи, що ми їх готові, належно поміркувавши, визнати за розсудкові» [5, с. 50-51]. I це міркування Дж. Ролза свідчить, як ми вже відзначали, що він не випадково $\epsilon$ класичним представником сучасного філософського дискурсу суспільної угоди, бо його головне завдання - створити теорію справедливості на засадах трансформованої теорії суспільної угоди.

Для досягнення цієї мети «не варто уявляти первісний договір як такий, що входить до котрогось конкретного суспільства чи запроваджує котрусь конкретну форму урядування. Радше провідна ідея тут та, що принципи справедливості для основної структури 
суспільства $є$ предметом первісної угоди. Це ті принципи, що вільні й розумові особи, зацікавлені в плеканні своїх власних інтересів, приймають їх у такій собі початковій позиції рівності як такі, що визначають фундаментальні умови їхнього осоціальнення. Ці принципи мають регулювати всі подальші домовленості; вони точно визначають ті типи соціальної співпраці, в які можна буде заходити, й ті форми урядування, що їх можна буде запроваджувати. Ось цей спосіб розглядання принципів справедливості я й називатиму справедливістю як чесністю» [5, с. 36-37].

Таким чином, йдеться поки не про реальну угоду, а про те, що нам варто спочатку уявити, що люди, які спільно діють, вибирають також і ті основні принципи, які визначають їх права та обов'язки (що дивним чином не помітили критики його теорії), а також способи розподілу суспільних благ. I стосується сказане не лише окремої людини, а й громади, спілки людей, які разом, розважливо та чесно вирішують, що є справедливим чи несправедливим. Більше того, у такому тлумаченні справедливості, як чесності, Ролзова первісна позиція рівності відповідає природному станові у традиційній теорії суспільної угоди. Ця первісна позиція не є реальним історичним станом справ. Це власне гіпотетична ситуація, якій властиві такі риси: «ніхто не знає свого місця в суспільстві, свого класового становища чи соціального статусу; ніхто не відає ні своєї частки в розподілі природних багатств, ні своїх здібностей, розуму, сили тощо. Я припущу навіть, що сторони не знають і своїх концепцій блага чи особливих своїх психологічних схильностей. Принципи справедливості вибираються за такою собі запоною незнання. Чим забезпечується те, що ніхто не знає ні своїх переваг, ні недоліків у вибиранні принципів із допомогою результату природного шансу чи випадковості соціальних обставин. Оскільки всі перебувають у подібному становищі й ніхто не здатен придумувати принципи на користь своєї конкретної ситуації, принципи справедливості стають наслідком чесної угоди чи домовленості» [5, с. 38].

Що ж власне є головним у тлумаченні Ролзом справедливості як чесності - принципи справедливості (які можна вважати масштабом для критики та реформи суспільних інституцій), погоджені та взаємообгрунтовані в початковій чесній ситуації. А громадяни сус- 
пільства, яке відповідає принципам справедливості як чесності, $\epsilon$ автономними, а визнані ними зобов'язання - добровільними. Ще раз наголосимо на важливому принципі політичної антропології Ролза: сторони суспільної угоди не є егоїстами, проте вони мусять припускати, що навіть їхні духовні інтереси можуть наштовхнутися на опір інших людей з протилежними інтересами.

Наступний крок Ролза - це визначення принципів справедливості, що будуть вибрані у первісній позиції, адже кожен з нас бажає захистити свої інтереси, свою спроможність просувати власну концепцію блага без втрат та розчарувань. Тому, на нашу думку, принцип корисності є несумісним з концепцією соціальної співпраці рівних та розумних людей. Проте Ролз переконливо доводить, що особи в окресленій вище початковій ситуації виберуть собі два головні принципи: перший з них вимагає рівності в оцінці основних прав та обов'язків, тоді як другий вважає, що соціальні й економічні нерівності, наприклад, нерівності багатства й авторитету, є справедливими лише тоді, коли наслідком їх постають компенсації для найменш привілейованих членів суспільства.

Отже, теорію справедливості Дж. Ролза можна коротко охарактеризувати як спробу поєднання принципів свободи та рівності за допомогою процедури, яку можна було б назвати «максимізацією мінімуму». А два сформульованих Ролзом основні «базові принципи справедливості» є осердям його контрактуалістичної «справедливості як чесності».

Не деталізуючи проблему вибору принципів, з'ясуємо чому, на думку Ролза, справедливість як чесність є прикладом теорії суспільної угоди. Адже «зміст релевантної угоди не слід відносити до котрогось даного суспільства чи прив'язувати до котроїсь даної форми урядування: він тільки має прийняти певні моральні принципи. До того ж заходи, на які я тут посилаюся, є суто гіпотетичними: всякий контрактаріанський погляд стверджує, що в добре визначеній початковій ситуації будуть прийняті певні принципи» [5, с. 44].

Звернемо також увагу на визначення Ролзом заслуги контрактуалістичного підходу, яка полягає в тому, що саме в цей спосіб можна пояснити й виправдати концепції справедливості. Теорію справедливості можна тлумачити як частину теорії розважливого вибору. А саме поняття «угода» натякає на розмаїття суперечливих пре- 
тензій на переваги, що здобуваються у соціальній співпраці; цю множинність, а також на те, що належний розподіл переваг має здійснюватися відповідно до принципів, прийнятних для всіх сторін.

Важливим пріоритетом поняття «угода» є гласність принципів справедливості. За висловом самого Ролза, «якщо ці принципи стали наслідком певної угоди, то громадяни володіють знанням про принципи, якими керуються інші. Наголошування на громадській природі політичних принципів характерне для «суспільно-договірних» теорій. Зрештою ж існує довга традиція вчення про суспільний договір. Вираження зв'язку з цією лінією філософської думки допомагає визначати ідеї й узгоджується 3 природним благочестям» [5, с. 44]. Наступна важлива та актуальна сьогодні теза Ролза: справедливість як чесність не є довершеною та завершеною теорією суспільної угоди, яку можна розширювати далі, до перетворення на засновок тлумачення не лише справедливості, а й інших чеснот. Проте, як критично зауважує Ролз, ця теорія не є універсальним методологічним принципом та онтологічним підходом.

Завдяки теорії справедливості Ролза (який, спираючись на кантівську версію суспільної угоди, виходить 3 того, що необхідно поважати кожного конкретного індивіда, а моральні принципи мусять бути виправданими щодо нього, тобто вимога дотримання чесної та неупередженої угоди зумовлена зовнішніми щодо неї причинами) сучасний філософський та політичний дискурс усвідомлює та розвиває далі думку про те, що заснована на принципах свободи та рівності ідея суспільної угоди є втіленням основних демократичних цінностей, демократичних способів регулювання взаємин громадян та влади. Створена ж Ролзом система принципів соціальної справедливості має свою (аналітично спрямовану) теорію раціональності, що набула подальшого осмислення та застосування в його «Політичному лібералізмі». Як наголошує О. Гьофе у своїх роздумах про «неметафізичний лібералізм Ролза», прагнення останнього - якщо не відмовитися, то оминути метафізичний спосіб мислення та «уникнути закидів в етноцентризмі, котрі виникають на адресу того, хто намагається надати універсалістського статусу розумінню права та держави у своїй культурі, витлумачуючи їх, хоча і непрямо, в якості 
зразка для інших культур» [6, с. 117] втілилося в розвитку ідеї справедливості.

I в «Теорії справедливості», і у своїй останній праці «Справедливість як чесність. Новий проект» [7] Ролз наголошує на тому, що справедливість як чесність мусить грунтуватися на притаманному всім чуттю справедливості. I теоретичні конструкції мусять коригуватися судженнями про справедливість доти, доки суперечність між ними не зникне. У цьому інтелектуальному річищі доцільно сподіватися на те, що основні ідеї та принципи справедливості можуть бути виоформлені у концепцію політичної справедливості, яка відповідала б найбільш усталеним переконанням. Завдяки Ролзу увага новітньої філософії концентрується на істотній зміні ролі особистості в тлумаченні проблем свободи та справедливості. Йдеться як про необхідність компромісів та врахування індивідуальних життєвих планів, так і про проблему легітимності влади та необхідних для іiі функціонування чуття справедливості та довіри. Ці роздуми Дж. Ролза про справедливість дають можливість поставити під сумнів деякі спрощені тлумачення його ідей та виокремити плідні критичні зауваження. До останніх належать праці А. Гонета, М. Нуссбаум, Е. Тугендгата та Р. Форста. Йдеться, насамперед, про межі розподільного тлумачення справедливості. Адже Джон Ролз, незважаючи на його спроби вийти за межі абстрактного універсалізму, залишає поза увагою головне питання справедливості, а саме - питання влади. А також виявляється неспроможним вирішити низку конкретних проблем, пов'язаних 3 порушенням гідності не лише немічних, а й здорових людей.

Проте теорію справедливості Ролза спіткала щаслива доля: жодна праця $з$ проблем справедливості неможлива без звернення, хай навіть критичного, до цієї теорії. У критичному ж осмисленні філософії справедливості Ролза варто, на нашу думку, виокремити щонайменше три спрямування. Крім названого вище прагнення Франкфуртської школи звернутися до проблеми влади як осердя проблеми справедливості, йдеться про спроби критики поглядів Ролза $з$ позицій комунітаризму. Найприкметнішою у цьому сенсі $є$ відома праця М. Сендела «Справедливість. Як діяти правильно?» [8]. Але викладені в ній дотепні приклади із сучасного (переважно американського) життя, а також ідея про те, що для досягнення справе- 
дливого суспільства необхідні «колективні роздуми про сенс гарного життя та створення суспільної культури, сприятливої неминучим суперечностям» [8, с. 261], так і не змогли зруйнувати цілісне, позбавлене суб’єктивності, бачення справедливості Ролзом. Зрештою, це визнає і сам Сендел, завершуючи 6-й розділ книги під назвою «Джон Ролз. Аргументи на користь рівності» такими словами: «Неважливо, чи досягне зрештою теорія справедливості Ролза перемоги чи зазнає занепаду, проте вона $є$ найпереконливішим доказом на користь суспільства більшої рівності серед тих, які колись пропонувала американська політична філософія» [8, с. 166]. Осмислення сутності та меж теорії справедливості Ролза неможливо уявити без роздумів Е. Тугендгата (особливо його «Лекцій з етики» [9]), який, критикуючи Ролза, вважає, що справедливий суспільний лад не може розбудовуватися лише на підставі внеску його громадян у контракт. Адже запропонований Ролзом гіпотетичний природний стан і заснований на ньому контракт є невдалим тому, що він стосується лише спроможних убезпечити себе дорослих та здорових людей. I насамкінець, ми мусимо тлумачити висхідну ситуацію як ситуацію необхідності виходу навіть за межі «позитивної свободи» та створення для кожного індивіда (і лише тоді суспільство може називатися справедливим) по-справжньому вільного простору для життя та розвитку» [9, с. 375]. Е. Тугендгат вважає моральні уявлення «джерелом» інституційної соціальної справедливості, і зрештою робить висновок, якого дотримується у своїй «реалістичній утопії» справедливості і Дж. Ролз, а саме: лише взаємна повага та довіра можуть заступити шлях атомарно-егоїстичній поведінці людей і заснувати такі чесноти, як солідарність та справедливість.

\section{ЛIТЕРАТУРА}

1. Габермас Ю. Залучення іншого: студії з політичної теорії. Львів : Астролябія, 2006. $416 \mathrm{c.}$

2. Гьофе О. Розум і право: Складові інтеркультурного правового дискурсу. Київ : Альтерпрес, 2003. 264 с.

3. Левінас Е. Етика і Безкінечність: діалоги з Філіппом Немо. Київ : Port-Royal, 2001. $140 \mathrm{c}$.

4. Рікер П. Право і справедливість. Київ : Дух і літера, 2002. 216 с. 
5. Ролз Дж. Теорія справедливості. Київ : Основи, 2001. 822 с.

6. Höffe O. Gerechtigkeit denken. John Rawls' epochales Werk der politischen Philosohie. München, 2021. 192 s.

7. Rawls J. Gerechtigkeit als Fairneß Ein Neuentwurf. Frankfurt am Main, 2003. $316 \mathrm{~s}$.

8. Sandel M. Justice. What's the richt thing to do? New York, 2010. $308 \mathrm{p}$.

9. Tugendhat E. Vorlesungen über Ethik. Frankfurt am Main., 1993. $400 \mathrm{~s}$.

\section{REFERENCES}

Habermas, J. (2006). Involvement of another: studies in political theory. Lviv: Astrolabya. [In Ukrainian].

Höffe, O. (2003). Mind and Law: Components of Intercultural Legal Discourse. Kyiv. [In Ukrainian].

Levinas, E. (2001). Ethics and Infinity: Dialogues with Philip Nemo. Kyiv. [In Ukrainian].

Ricœur, P. (2002). Law and justice. Kyiv: Dukh i litera. [In Ukrainian].

Rawls, J. (2001). Theory of Justice. Kyiv: Osnovy. [In Ukrainian].

Höffe, O. (2021). Gerechtigkeit denken. John Rawls' epochales Werk der politischen Philosohie. München: C. H. Beck. [In German].

Rawls, J. (2003). Gerechtigkeit als Fairneß Ein Neuentwurf. Frankfurt am Main. [In German].

Sandel, M. (2010). Justice. What's the richt thing to do? New York.

Tugendhat, E. (1993). Vorlesungen über Ethik. Frankfurt am Main. [In German].

\section{Dmytro Usov}

Doctor of Philosophical Sciences, Professor, Cherkasy Institute of Fire Safety named after Chornobyl Heroes of National University of Civil Protection of Ukraine; Cherkasy, Ukraine; e-mail: dimausov@i.ua; ORCID: https://orcid.org/0000-0002-8898-9743 


\section{The philosophy of justice in the realistic utopia of John Rawls Abstract}

The article consistently substantiates the idea of the special methodological and practical relevance of the philosophy of justice by J. Rawls devoted to the 50th anniversary of the publication of his "Theory of Justice" and the 100th anniversary of the birth of this outstanding modern philosopher. Not only "Theory of Justice", but also such important works of J. Rawls as "Lectures on the History of Moral Philosophy" and "Justice as Fairness: A Restatement" are aimed at searching out the ways of building an honest, dignified society and appearing in front of us as the most influential texts of the last century on political philosophy, philosophy of law and morality. To think about "justice as fairness" with Rawls is a constructive philosophical strategy. This very idea is advocated not only by followers but also by critics of Rawls's theory of justice. As the article emphasizes, beginning the ponders on the question of justice, J. Rawls notes that justice, as a fundamental condition of human existence, does not allow the loss of freedom by some to be justified by the great benefits of others. What was embodied in the desire of his "realistic utopia of justice" is to work out the mechanisms for the fair overcoming of social conflicts. And the unconditional importance of suggested by us consistent reconstruction of the relationship between justice and freedom in the thoughts of J. Rawls is also due to the fact that they led to the deep development of modern social and political philosophy, broadened its methodological and conceptual horizons. However, Rawls's philosophy of justice (as emphasized by such prominent philosophers as A. Honneth, M. Nussbaum, $E$. Tugendhat, $R$. Forst) did not go beyond the distributive interpretation of justice and ignored the main issue of justice (and injustice) is the issue of power.

Keywords: John Rawls, justice, freedom, principles of justice, justice as honesty, political philosophy. 